\title{
POST-SURGE TEMPERATURES IN STEELE GLACIER, YUKON TERRITORY, CANADA
}

\author{
By Garry K. C. Clarke and Gary T. Jarvis \\ (Department of Geophysics and Astronomy, University of British Columbia, Vancouver, \\ British Columbia V6T I W5, Canada)
}

\begin{abstract}
Aвstract. Deep ice temperatures measured at four widely spaced sites on Steele Glacier show that the thermal regime was profoundly influenced by the $1965-66$ surge advance. Three of four measured temperature profiles are "anomalous" in that the upper roo $\mathrm{m}$ of ice is far from thermal equilibrium. Water penetration during the surge is the probable cause of these anomalies. Insufficient data are available to predict the basal ice temperature.

RÉsumé. Températures après crues au Steele Glacier, Territoire du Yukon, Canada. Des températures profondes mesurées en quatre points largement espacés sur le Steele Glacier, montrent que le régime thermique a été profondément influencé par la crue de $196_{5}-66$. Trois des quatre profils de température mesurés, sont "anormaux" en ceci que les $100 \mathrm{~m}$ supérieurs de glace sont loin de l'équilibre thermique. La pénétration d'eau pendant la crue est la cause probable des ces anomalies. Les données disponibles sont insuffisantes pour prévoir la température de la glace sur le fond.

Zusammenfassung. Temperaturen nach dem Ausbruch im Steele Glacier, Yukon Territory, Kanada. Eistemperaturen in der Tiefe, gemessen an vier weit auseinanderliegenden Stellen des Steele Glacier, zeigen, dass der Wärmehaushalt durch den Ausbruchsvorstoss von $1965^{-66}$ stark gestört wurde. Drei der vier gemessenen Temperaturprofile sind insofern "anomal", als sich das Eis in den obersten $100 \mathrm{~m}$ weit vom thermischen Gleichgewicht befindet. Der Grund für diese Anomalien liegt vermutlich im Eindringen von Wasser während des Ausbruches. Die vorliegenden Daten reichen nicht zu einer Bestimmung der Eistemperatur am Untergrund aus.
\end{abstract}

\section{INTRODUCTION}

The ${ }_{1965-66}$ surge of Steele Glacier, Yukon Territory, Canada, is one of the best documented surge advances of a large glacier. Field work by Wood (1936, 1942) and Sharp (1943, 195 I) provided much information about the pre-surge condition of the glacier, and the onset of the surge phase was detected by A. S. Post in the fall of 1965 . Although there is an unfortunate gap in information for the period between Post's surge prediction and the peak of surge activity in mid-1966, a number of useful observations were made during the decline of the surge phase (Bayrock, 1967; Stanley, 1969; Thomson, 1972).

Prior to July 1972 geophysical measurements on Steele Glacier were lacking, but investigations of two small surge-type glaciers near the Steele gave a consistent picture of the relationship between ice temperature and depth for pre-surge glaciers in the region: both glaciers were cold with large regions of temperate or near-temperate basal ice. This evidence was taken as support for thermal control of the surges. Although the Steele is much larger than the two glaciers studied previously, it seems reasonable that all of the eighteen probably surge-type glaciers of the Steele Creek basin surge by the same mechanism. Results of the 1972 reconnaissance drilling program on Steele Glacier (Jarvis and Clarke, 1974) left the question of the Steele's surge mechanism unsettled, but did indicate that the $1965-66$ surge had greatly disturbed the thermal regime in the middle zone of the glacier.

Deep drilling at three additional sites in 1973 and subsequent ice temperature measurements taken in 1974 provide further evidence of anomalous temperatures. The four deepdrilling sites, all located below the firn line, are indicated in Figure I. Surging of tributary glaciers such as the Hodgson Glacier and several unnamed glaciers leads to some confusion as to what ice is original to the Steele Glacier and what flows from tributaries. Medial moraines allowed the ice origin to be traced and it is thought that all drilling sites were located on ice flowing from either of the two main arms of the Steele. Drilling sites 73-2 and 73-3 were located in a region which prior to the last surge was covered by stagnant debris-laden ice; sites 72-I and 73-I were in the zone which remains active during the quiescent phase. All sites except 73-3 were in severely crevassed regions of extending flow during most of the surge. 


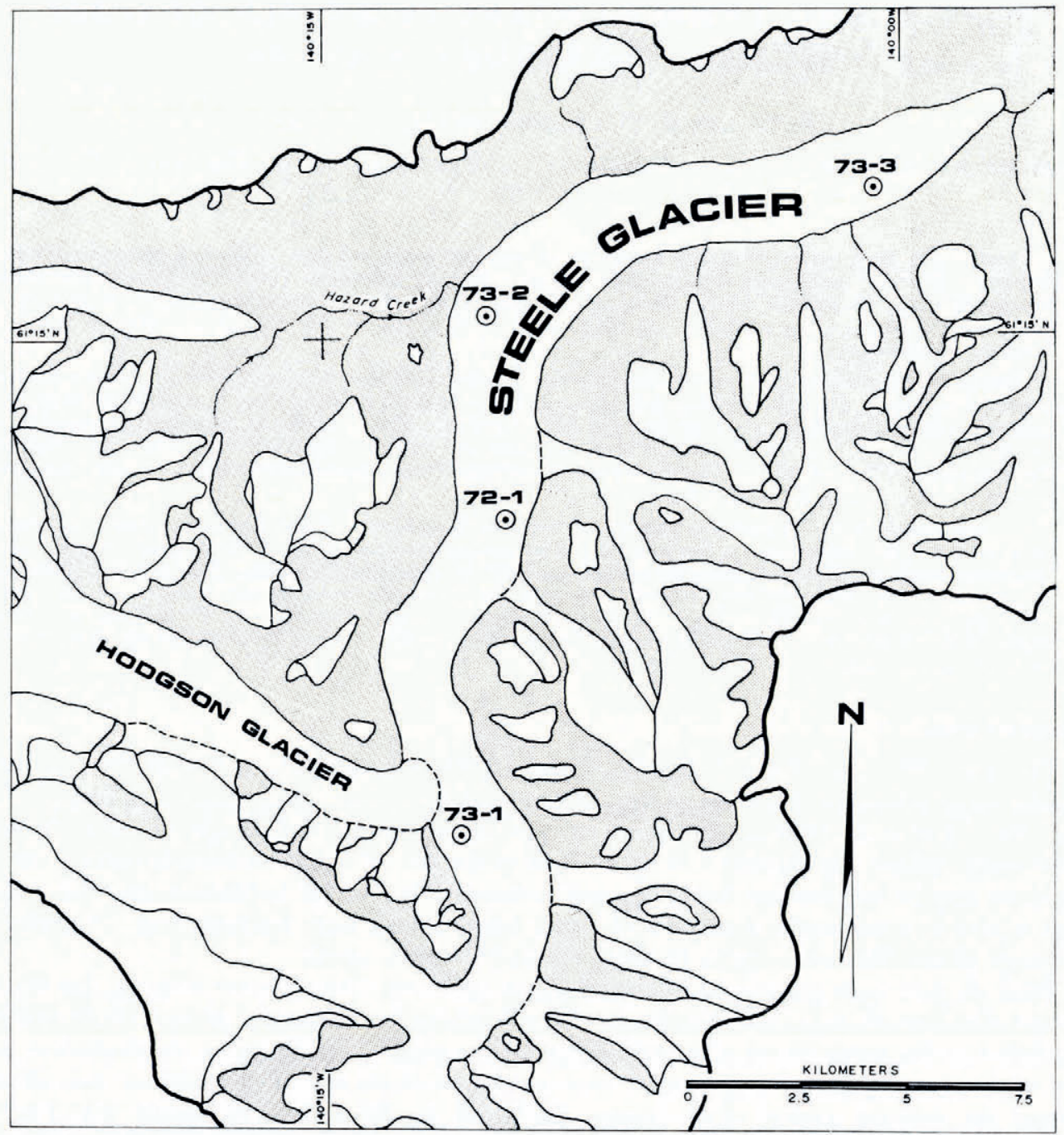

Fig. I. Locations of 1972 and 1973 thermal drilling sites on Steele Glacier.

\section{Measurements And Results}

Holes were thermally drilled using several different modifications of Aamot's (I968) buoyancy-stabilized probes. From past experience we found that buoyancy chambers reduced thermal contact and hence drilling rate; this disadvantage more than outweighed the merits of self-steering so the air chambers were filled with epoxy resin. Glass-beaded thermistors calibrated in the laboratory to an accuracy of \pm 0.04 deg were connected to 8 -conductor cable and allowed to follow the thermal probe through the ice. No attempt was made to recover the probes. More complete details of probe design, thermistor calibration and field procedures are given elsewhere (Classen and Clarke, 1972; Jarvis, unpublished).

Thermistor resistances were measured in September 1974, more than one year after completion of thermal drilling. A Fluke 81 $100 \mathrm{~A}$ digital multimeter and a Danameter 2000 were used to make these measurements to a final accuracy of $\pm 0.075 \mathrm{deg}$. 
Table I lists the observed ice temperatures with depth at the four sites, together with the dates of drilling and temperature measurement. The codes $72 \mathrm{~T}_{10}, 7_{2} \mathrm{~T}_{\mathrm{I}}$, etc., label thermistor cables. Temperatures indicated as greater than $0.00^{\circ} \mathrm{C}$ were for thermistors which had melted out of the ice and were lying on the glacier surface. The temperature profile for site 72-I (referred to the 1972 ice surface) is presented as Figure 2. The anomalous reversed temperature gradient between $45 \mathrm{~m}$ and $115 \mathrm{~m}$ is probably due to water injection into crevasses formed during the surge. A theoretical temperature curve for the effect of a spatially periodic field of partially water-filled crevasses on ice temperature agrees well with observations. The holes drilled at site 73-I above the confluence of the Hodgson Glacier show a similar inversion which can also be accounted for in this way (Fig. 3). The input parameters for the crevasse models used in generating the theoretical curves in Figures 2 and 3 are given

TABle I. Results of ICE temperature measurements

Site $72-I$

Depths referred to I August 1972 ice surface; temperatures measured on 27 July 1973

Thermistor cable Thermistor depth Ice temperature

$\begin{array}{rrr}72 \mathrm{~T} \text { 10 } & 70.3 & -3.99 \\ & 82.3 & -4.81 \\ & 92.3 & -5.45 \\ 100.3 & -5.92 \\ 106.3 & -6.16 \\ & 112.3 & -6.47 \\ 72 \mathrm{~T}_{11} & 114.3 & -6.51 \\ & 26.0 & -2.91 \\ & 33.0 & -1.93 \\ & 40.0 & -1.87 \\ & 47.0 & -1.45 \\ & 54.0 & -1.83 \\ & 61.0 & -2.46\end{array}$

Site 73-2

Depths referred to 26 July 1973 ice surface; temperatures measured on 5 September 1974

Thermistor cable Thermistor depth Ice temperature

$\begin{array}{rrr}73 \mathrm{~T}_{4} & 27.4 & -0.85 \\ & 42.7 & -0.86 \\ & 57.9 & -0.90 \\ 73 \mathrm{~T}_{5} & 73.2 & -0.87 \\ & 0.6 & >0.00 \\ & 31 . \mathrm{I} & -0.79 \\ & 61.6 & -0.86 \\ & 76.8 & -1.02 \\ 73 \mathrm{~T} 6 & 92.0 & -0.81 \\ & 107.3 & -0.59 \\ & 3.0 & >0.00 \\ & 6.0 & -0.88 \\ & 9.0 & -3.64 \\ & 12.0 & -4.01 \\ 73 \mathrm{~T}_{7} & 15.0 & -3.04 \\ & 18.0 & -1.47 \\ & 1.4 & >0.00 \\ & 4.4 & >0.00 \\ & 7.4 & -1.35 \\ & 10.4 & -2.40 \\ & 13.4 & -1.99 \\ & 16.4 & -1.27\end{array}$

Site 73-I

Depths referred to 19 July 1973 ice surface; temperatures measured on 5 September 1974

Thermistor cable Thermistor depth Ice temperature

$\begin{array}{rrr}73 \mathrm{~T}_{1} & \text { 10.1 } & -4.2 \mathrm{I} \\ 73 \mathrm{~T}_{2} & 40.5 & -1.47 \\ & 3.0 & >0.00 \\ & 6.0 & -3.56 \\ & 9.0 & -4.51 \\ & 12.0 & -3.82 \\ & 15.0 & -2.88 \\ 73 \mathrm{~T}_{3} & \text { 18.0 } & -2.08 \\ & 21.0 & -1.68 \\ & 24.4 & -1.16 \\ & 39.6 & -1.19 \\ & 54.9 & -2.24 \\ & 67.1 & -3.35\end{array}$

Site 73-3

Depths referred to 28 fuly 1973 ice surface; temperatures measured on 5 September 1974

Thermistor cable Thermistor depth Ice temperature

$73 \mathrm{~T} 8$

$\begin{array}{rr}31.7 & -3.00 \\ 40.8 & -2.19 \\ 50.0 & -2.21 \\ 59.1 & -0.87 \\ 68.3 & -0.45 \\ 77.4 & -0.20 \\ 86.6 & -0.02 \\ 3.0 & -0.91 \\ 6.0 & -4.06 \\ 9.0 & -5.55 \\ 12.0 & -5.62 \\ 15.0 & -4.97 \\ 18.0 & -4.49 \\ 21.0 & -4.09\end{array}$




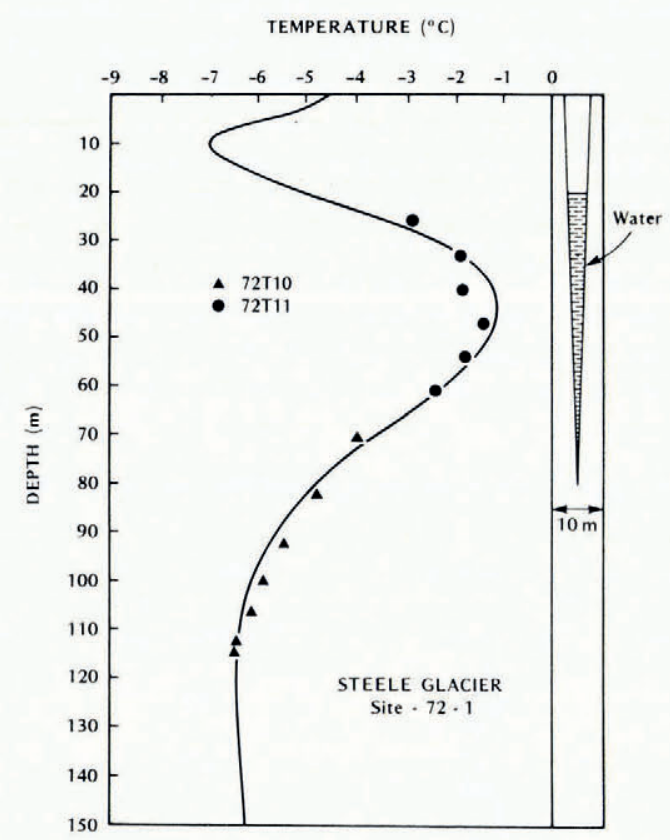

Fig. 2. Measured ice temperature with depth in hole at site 72-I. The smooth curve is the predicted temperature with depth at a time 7.5 years after the surge onset assuming a spatially periodic field of partially water-filled crevasses was formed during the surge.

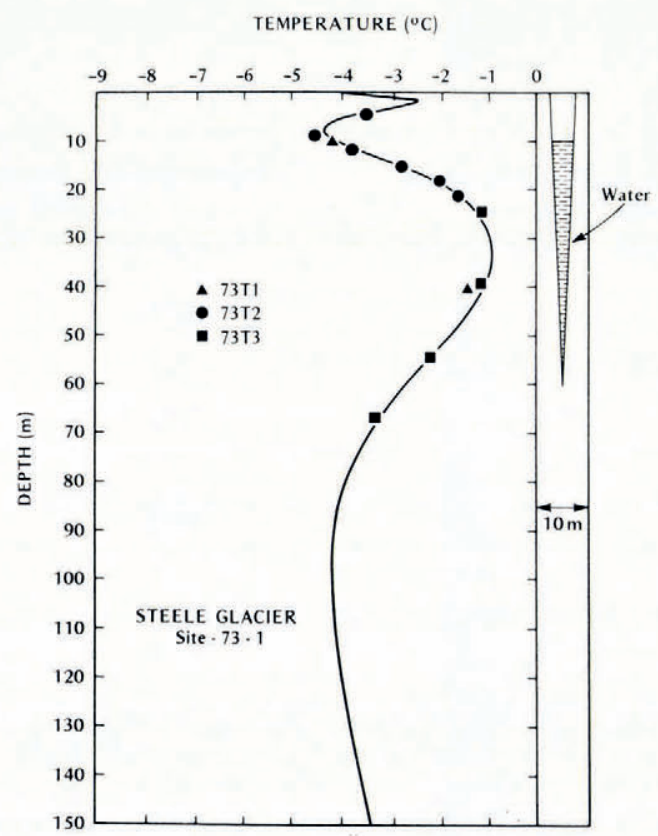

Fig. 3. Measured ice temperature with depth in holes at site 73-I near the confluence with Hodgson Glacier. The smooth curve is the predicted temperature with depth at a time 8.5 years after the surge onset assuming a spatially periodic field of partially water-filled crevasses was formed during the surge. 
in Table II; details of the numerical model have been published previously (Jarvis and Clarke, 1974). Because final temperatures at sites $72-\mathrm{I}$ and $73^{-1}$ were not measured in the same summer field season, the theoretical curves plotted in Figures 2 and 3 are evaluated at times appropriate to each set of measurements.

\section{Table II. Crevasse model parameters}

$\begin{array}{lcc} & \text { Site } 72-I & \text { Site } 73-I \\ \text { Crevasse separation } & 30 \mathrm{~m} & 30 \mathrm{~m} \\ \text { Crevasse width } & 5 \mathrm{~m} & 5 \mathrm{~m} \\ \text { Crevasse depth } & 80 \mathrm{~m} & 60 \mathrm{~m} \\ \text { Depth to water surface } & 20 \mathrm{~m} & 10 \mathrm{~m} \\ \text { Mean surface temperature } & -8.00^{\circ} \mathrm{C} & -6.00^{\circ} \mathrm{C} \\ \text { Temperature at } 150 \mathrm{~m} \text { depth } & -6.25^{\circ} \mathrm{C} & -3.50^{\circ} \mathrm{C}\end{array}$

A second type of anomalous profile was measured at site $73^{-2}$ near the "big bend" in Steele Glacier $15 \mathrm{~km}$ below the confluence with Hodgson Glacier (Fig. 4). The nearly isothermal temperature distribution cannot be an equilibrium feature and probably is the result of extreme water penetration through a relatively thick ( $100-200 \mathrm{~m}$ ) layer of fractured ice. The profile labelled $73 \mathrm{~T}_{7}$ was measured in a hole located approximately $70 \mathrm{~m}$ from the other holes at this site and at a distance of $20 \mathrm{~m}$ from an active moulin. It is interesting that this moulin exists in non-temperate ice and illustrates that internal drainage is not a feature unique to temperate glaciers.

The only temperature profile which could be characterized as "normal" was measured at site 73-3 in the moraine-covered stagnant ice near the snout (Fig. 5). In this case the temperature increases regularly with depth and attains the melting point at approximately $85 \mathrm{~m}$. Similar profiles have been observed on the nearby Rusty and Trapridge Glaciers

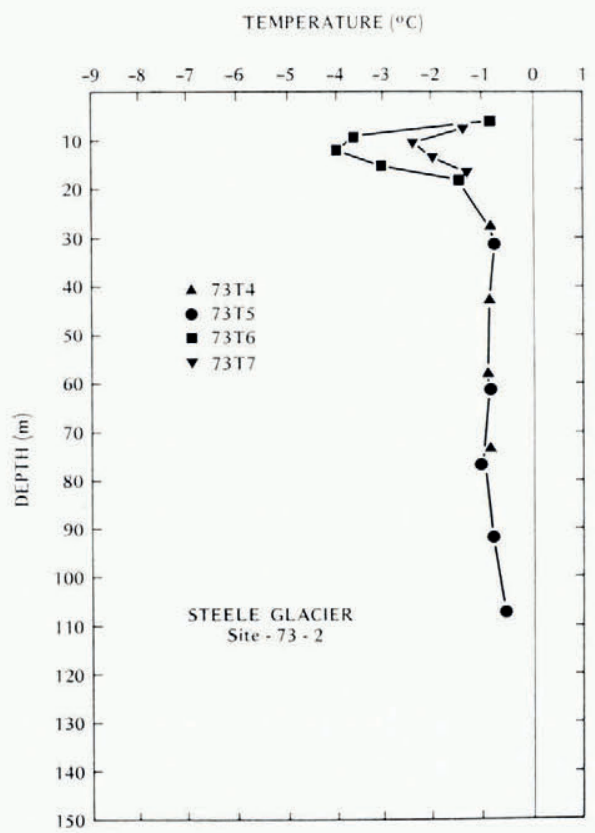

Fig. 4. Measured ice temperature with depth in holes drilled at site 73-2 near the "big bend" of Steele Glacier. The shallow hole ${ }_{73} T_{7}$ was drilled $20 \mathrm{~m}$ from a moulin and is located approximately $70 \mathrm{~m}$ from the remaining holes at this site. 
(Clarke and Goodman, I975; Jarvis and Clarke, 1975). No soundings have been attempted on the Steele so it is not certain whether a thick layer of temperate ice lies below site 73-3 or whether the probe reached the bed. The slope discontinuity in temperature near $50 \mathrm{~m}$ is too large to be due to poor calibration or resistance measurement. At this site all thermistors were measured at least six times using two different meters; calibration accuracy for all thermistors at this site was better than $\pm 0.015 \mathrm{deg}$. As numerical modelling experiments (Clarke, I976) predict temperature kinks near the snout of a cold glacier that has recently surged, the feature is probably real. The lifetime of the present thermal anomaly at site 73-3 is less than ten years.

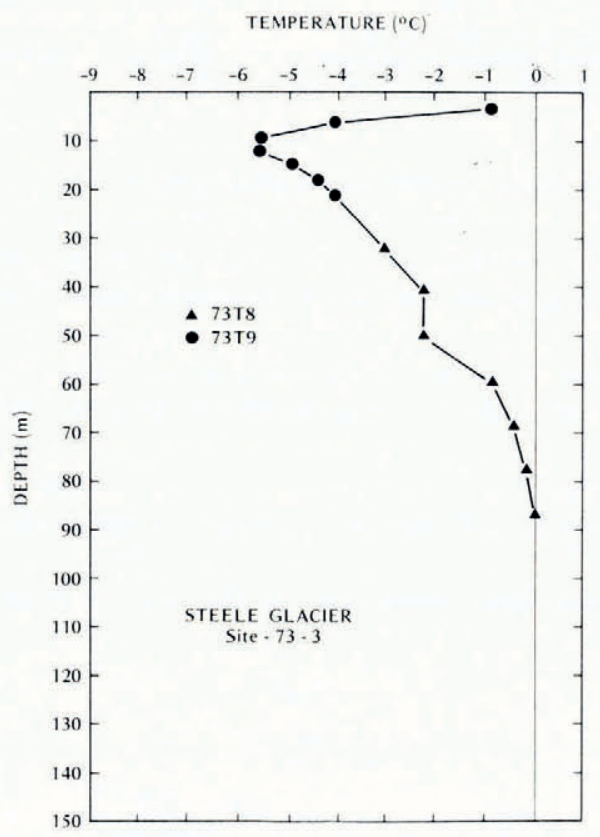

Fig. 5. Measured ice temperature with depth at site $73-33.5 \mathrm{~km}$ from the 1973 terminus.

With three of the four temperature profiles clearly "anomalous" it is premature to make generalizations concerning Steele Glacier's thermal regime. Water penetration has greatly disturbed the temperature of the near-surface ice and our measurements were not sufficiently deep to allow prediction of the deep regime. We conclude that surging glaciers can have a very complex thermal structure which would not necessarily be revealed by shallow temperature measurements at a small number of sites. It is possible that some of these glaciers which have been identified as temperate from near-surface temperature may, in part, be sub-polar.

\section{AgKNOWLedgements}

We thank Environment Canada, the University of British Columbia Committee on Arctic and Alpine Research, and the National Research Council (Canada) for financial support, and the Arctic Institute of North America for logistic support in the field. B. Chandra, D. F. Classen, B. B. Narod and K. D. Schreiber assisted with field preparations and R. Metcalfe was a congenial and capable field assistant. The co-operation of the National Parks Service, Kluane National Park, is gratefully acknowledged. 


\section{REFERENCES}

Aamot, H. W. C. 1968. A buoyancy-stabilized hot-point drill for glacier studies. Fournal of Glaciology, Vol. 7, No. 5i, p. $493-98$.

Bayrock, L. A. 1967 . Catastrophic advance of the Steele Glacier, Yukon, Canada. Alberta University. Boreal Institute. Occasional Publication No. 3.

Clarke, G. K. C. I976. Thermal regulation of glacier surging. Fournal of Glaciology, Vol. i6, No. 74, p. 231-50.

Clarke, G. K. C., and Goodman, R. H. 1975. Radio echo soundings and ice temperature measurements in a surge-type glacier. Fournal of Glaciology, Vol. 14, No. 70, p. 7i-78.

Classen, D. F., and Clarke, G. K. C. 1972. Thermal drilling and ice-temperature measurements in the Rusty Glacier. (In Bushnell, V. C., and Ragle, R. H., ed. Icefield Ranges Research Project. Scientific results. Vol. 3. New York, American Geographical Society; Montreal, Arctic Institute of North America, p. 103-16.)

Jarvis, G. T. Unpublished. Thermal studies related to surging glaciers. [M.Sc. thesis, University of British Columbia, 1973.]

Jarvis, G. T., and Clarke, G. K. C. 1974. Thermal effects of crevassing on Steele Glacier, Yukon Territory, Canada. Journal of Glaciology, Vol. i 3 , No. 68, p. 243-54.

Jarvis, G. T., and Clarke, G. K. C. 1975. The thermal regime of Trapridge Glacier and its relevance to glacier surging. Journal of Glaciology, Vol. 14 , No. 71, p. 235-50.

Sharp, R. P. 1943. Geology of the Wolf Creek area, St. Elias Range. Bulletin of the Geological Society of America, Vol. 54, No. 5, p. 625-5o.

Sharp R. P. i95I. The glacial history of Wolf Creek, St. Elias Range, Canada. Journal of Geology, Vol. 59, No. 2, p. $97^{-1} 17$.

Stanley, A. D. 1969 . Observations of the surge of Steele Glacier, Yukon Territory, Canada. Canadian Fournal of Earth Sciences, Vol. 6, No. 4, Pt. 2, p. 819-30.

Thompson, S. 1972. Movement observations on the terminus area of the Steele Glacier, July 1967. (In Bushnell, V. C., and Ragle, R. H., ed. Icefield Ranges Research Project. Scientific Results. Vol. 3. New York, American Geographical Society; Montreal, Arctic Institute of North America, p. 29-37.)

Wood, W. A. 1936. The Wood Yukon expedition of 1935: an experiment in photographic mapping. Geographical Review, Vol. 26, No. 2, p. 228-46.

Wood, W. A. 1942. The parachuting of expedition supplies. Geographical Review, Vol. 32, No. 1, p. $3^{6-55}$.

\section{DISCUSSION}

G. DE Q. RobIN: How long will it take for the water body in the crevasse to freeze completely? Could the anomaly at your lowest station be due to a very old water pocket that has been carried down?

G. K. C. Clarke: Neither of the two crevasse models presented was run until the water pockets froze solid, but I would guess that complete freezing should occur 20-30 years after the time of the surge. It is certainly possible that thermal anomalies of the sort we observe do not disappear completely during the quiescent phase so that when the next Steele surge occurs the temperature will still be disturbed from the $1965-66$ surge. I agree that the anomaly at Site 73-3 could be caused in this way. We have computed several models in which we have two different crevasse-opening events, i.e. surges, but do not allow for ablation at the glacier surface, which must have a significant influence.

W. S. B. Paterson: I note that you regarded crevasse depth as a variable parameter. Have you made any measurements?

Clarke: There are no longer any open crevasses near our drilling sites so we could not make this measurement.

J. W. GLEN: Most studies of crevasse depths are based on normal, slow glaciers. In a surging glacier, especially with good water supply, I do not see why any depth is unthinkable.

C. F. RAYmond: Do you think penetration of water into moulins during the quiescent phase of flow represents a significant heat transport mechanism, which needs to be considered in calculating the evolution of temperature between surges? 
Clarke: I find it hard to imagine that a significantly dense network of drainage channels exists within the glacier to cause a major thermal disturbance.

M. F. Meier: In July of I 966 one could see water in many crevasses, in some cases right next to crevasses which were completely dry. If one assumes that water is getting into all crevasses, then one must surmise that it also can escape from some. Perhaps the water escapes because these crevasses are very deep. 